\title{
TRAJETÓRIAS PESSOAIS E AS PAISAGENS DO POSSÍVEL: PERCURSO, MEMÓRIA E NARRAÇÃO
}

\author{
Flávio Leonel Abreu da Silveira ${ }^{1}$
}

\section{A guisa de introdução}

Quando, em 2010, recebi a solicitação de Cornelia Eckert e Ana Rocha para falar sobre a minha trajetória pessoal e acadêmica no "II Colóquio Individualismo, Sociabilidade e Memória", juntamente com dois colegas antropólogos, confesso que me surpreendi com o convite. O espanto advinha do fato de que, pertencendo eu a uma geração mais nova de antropólogos brasileiros, considerava a minha trajetória pessoal dentro do campo da Antropologia ainda muito recente e, de certa forma, particular - não só porque minha, obviamente, mas por não ser oriundo das Ciências Sociais - somandose a isto o fato de que a sua construção envolve um grande esforço pessoal - e emocional - para lidar com a timidez que trago comigo desde a infância.

Percebo que a minha experiência junto à disciplina figura no cenário acadêmico como uma trajetória profissional em consolidação entre os meus pares, principalmente, se pensá-la em relação às gerações mais velhas de antropólogos, entre as quais estão alguns que admiro muito. Ora, as duas pessoas que me convidavam a falar para estudantes de pós-graduação da Universidade Federal do Rio Grande do Sul (UFRGS) -, no meu ponto de vista pessoal e profissional, se destacam entre aqueles intelectuais que considero inspiradores no cenário da Antropologia realizada no país.

O desafio proposto por ambas, desta forma, colocava a necessidade de ordenar objetivamente as minhas memórias pessoais acerca do que vivi diante do que experiencio no contemporâneo como indivíduo que optou por investir na vida acadêmica enquanto um projeto (Velho, 1994), tendo, por isso, que avaliar subjetivamente a minha trajetória biográfica diante do campo de possibilidades e das escolhas que se apresentaram ao longo do percurso trilhado por mim.

Ambas me levavam a pensar sobre o processo de construção de uma carreira acadêmica que se encontra em andamento, o que implicava ponderar acerca das instituições por onde transitei como estudante de graduação e de pós-graduação, professor e pesquisador ao longo dos 26 anos em que me encontro envolvido com o mundo acadêmico, considerando que entre 1984 e 1990 realizei a graduação em

\footnotetext{
${ }^{1}$ Universidade Federal do Pará, Brasil.
} 
Licenciatura em Biologia na Universidade do Vale do Rio dos Sinos (UNISINOS); Especialização em Ecologia Humana (1992-93) na mesma instituição; Mestrado em Antropologia Social na Universidade Federal de Santa Catarina (UFSC) no período de 1994-96; e doutorado na Universidade Federal do Rio Grande do Sul (UFRGS) entre 2000-04.

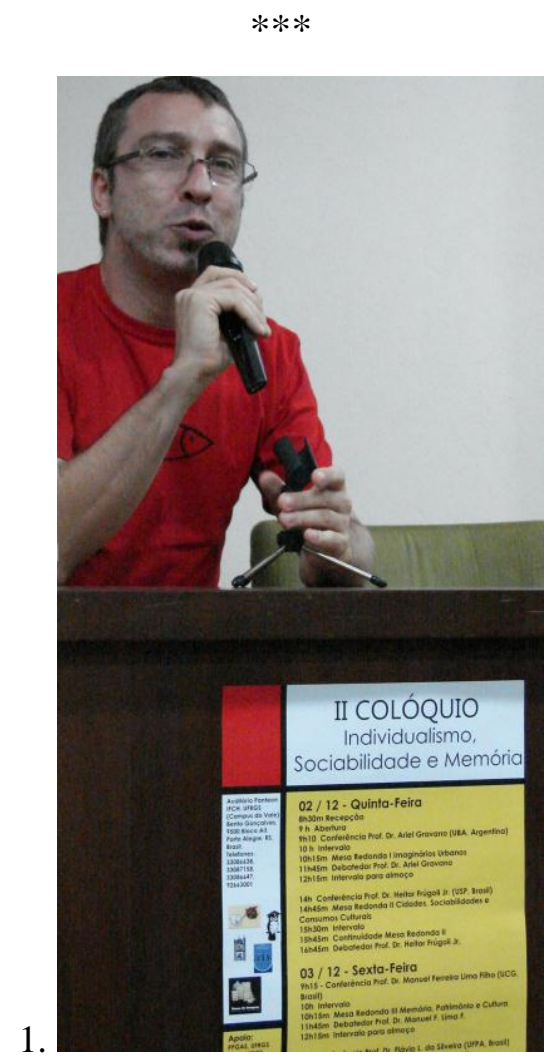

Prof. Flávio Leonel da Silveira. Foto de 03 de dezembro 2010. Conferência no II Colóquio Individualismo, Sociabilidade e Memória. Sala Pantheon IFCH UFRGS. Acervo BIEV PPGAS IFCH UFRGS

A provocação, desta forma, incitava-me à realização de uma espécie de percurso subjetivo por minhas memórias, através do qual poderia mergulhar neste universo próximo-distante de vivências e escolhas tanto pessoais quanto intelectuais desde a formação na graduação e na pós; minha atuação como docente em diversas instituições de ensino; como pesquisador/consultor ${ }^{2}$, o que incluía a passagem pela própria instituição na qual falaria naquele momento, uma vez que realizei o doutoramento sob a orientação das organizadoras do evento.

\footnotetext{
${ }^{2}$ Incluo a minha inserção no Terceiro Setor, neste caso, junto ao Instituto Anthropos entre os anos de 1996 a 2004 - quando atuei ativamente com o grupo. Retomarei a questão mais adiante.
} 
Por isso mesmo, tal aventura pelos meandros de minhas memórias biográficas fazia-me lidar com as suas lacunas, esquecimentos e hesitações diante do que lembrava e do que neste esforço, seletivamente, entendia ser importante indicar a fim de tecer uma narrativa capaz de dar conta de uma trajetória de vida, envolvendo, por certo, afetos e tensões; alegrias e conflitos; escolhas e imponderáveis; vivências e formas de exercer o trabalho de campo nos diferentes âmbitos de minha formação - Biologia; Ecologia Humana e Antropologia Social -; entre outras experiências que acumulara no percurso ao longo de uma vida.

Portanto, retornava a casa. Não como o pródigo que regressa arrependido, mas como filho autônomo que percorreu outras paisagens e que revisita a antiga morada porque nela reencontra o lugar que deixou outrora. Todavia, ambos configuravam um cenário em transformação porque nem um nem outro permanecera o mesmo. Daí que após diversos vôos revia aquela ambiência, se não totalmente imerso no imaginário de estabilidade do ninho-refúgio bachelardiano, não menos como ponto de pouso e mirada - de onde aprendi a valorizar certos pontos de vista e a vislumbrar novos horizontes. Tratava-se de um abrigo conhecido que se revisita de tempos em tempos como uma paisagem de repouso antes de retomar o curso.

O meu intento neste ensaio (auto)biográfico, uma vez que trata das minhas memórias, é o de (re)situar o meu lugar neste panorama que esbocei a partir do olhar que lanço não só a minha trajetória pessoal e profissional - por sinal, impossível de separá-las -, motivo que me levou desde o norte ao sul do país para dialogar com a minha comunidade de linguagem e que o colóquio proporcionou, mas, também, de revisitar as emoções vividas no reencontro com as paisagens afetivas do campus - os espaços edificados; as pessoas amigas ou as conhecidas de vista; o café com bolinho de queijo no Bar do Antonio; os jacarandás floridos e os sabiás cantadores - e o processo reflexivo que naquele momento me forçou a repensar as minhas opções e os caminhos que trilhei diante do reconhecimento de que teria o que dizer sobre isso, especialmente, aos mais jovens.

Ora, ao deparar-me com tal situação percebi que eu mesmo precisaria redimensionar a forma como percebia o meu percurso, dando novos sentidos a isso tudo que me constitui como sujeito no mundo inserido em papéis e situações diversas nas últimas duas décadas, no que se refere à produção de conhecimentos e que evoca imagens - fragmentárias; meio apagadas; vívidas - de uma experiência biográfica em devir porque aberta a realizações futuras, onde o presente é esse diálogo constante com 
o passado das minhas possibilidades, esforços e desígnios pessoais ao longo do meu tempo vivido e subjetivo.

Passados alguns meses do evento recebo a incumbência de textualizar o meu empenho de diálogo com os meus pares já que algo do que falei à época ainda reverbera como imagem de uma experiência pessoal e acadêmica diante de outras pessoas que constroem as suas enquanto percorrem o campus e as rampas que conduzem ao PPGAS como eu fiz um dia. Este exercício de escrita de si é, portanto, um esforço que empreendo a fim de lidar com as memórias pessoais que compõe a minha trajetória de vida de maneira a contextualizá-las diante do meu tempo que é o tempo de um homem que nasceu no turbulento século XX e que vislumbra no alvorecer deste XXI a possibilidade, utópica, talvez, de produzir conhecimento em um país que se reinventa apesar de seus dilemas.

\section{Acerca de mim, ou o si mesmo como processo e devir no exercício etnográfico}

A minha formação em Antropologia Social começa na primeira metade da década de 90 sob o signo de certo "barulho", para retomar uma imagem que Trajano Filho (1986) evocou acerca de alguns autores que à época, se não traziam questões totalmente novas, pelo menos as colocavam sob outra perspectiva no campo antropológico. Desta forma, precisávamos ler os clássicos porque fundamentais a nossa formação - e o apelo de Ítalo Calvino ainda vibra com força -, contudo, certa bibliografia nos convidava a colocá-los em suspeição. Sendo assim, à medida que líamos também os autores brasileiros que se voltavam ao tema percebíamos que certa onda desconstrutivista poderia derrubar certos cânones sem muito a oferecer em seu lugar. Portanto era necessário, também, desconfiar de quem nos incitava a desconfiar. Talvez esta fosse à força que a questão imprimia, uma vez que na América Latina, tal tema nos alcançava de outras formas.

O impacto de tais sonoridades desestabilizadoras surgidas desde a hermenêutica, figurando como desdobramento seu e, por isso, pós-geertziana, no âmbito da produção antropológica contemporânea afetava de maneira direta as formas de considerar os jogos de poder no corpo da matriz disciplinar antropológica, que Cardoso de Oliveira (1986) nos solicitava a refletir diante de certa "crise de paradigmas". Ora se não se tratava de um sedutor e hipnótico canto de sereias pelo menos desestabilizava um equilíbrio próprio de ouvidos moucos, quando não escutam além do que pode ser o conveniente no campo científico. 
Se o impacto de Writing Culture ou de Anthropology as cultural critique sob os estudantes fazia-nos repensar o que líamos, da mesma forma o impacto de Uma Antropologia no Plural e de A favor da etnografia - obras fundamentais de Marisa Peirano (1992; 1995) - nos forçava à suspeição por uma espécie de redundância, ou seja, precisávamos de alguma maneira antropofagizar o pensamento inquieto dos críticos sob a nossa ótica, colocando-o também sob suspeição num quadro de tensões oriundas do colonialismo e de certa crença no pós-colonialismo, quando na verdade era preciso pensar as formas de neo-colonialismo que continuavam emergindo aqui ou ali no contexto brasileiro e mundial.

Portanto, a minha geração foi formada neste contexto acadêmico de tensões que precisava considerar o retorno do autor e suas idiossincrasias; a subjetividade presente no ofício do antropólogo, problemática que aponta para o dilema razão-emoção que se imbrica na persona do antropólogo - figuras como Simmel e Mauss traziam questões tão importantes para pensarmos quanto Favret-Saada ou Crapanzano -, assim como nos colocava o próprio evento "etnografia" como um estar lá situado em relação ao Outro, daí a intersubjetividade - que de alguma maneira o anthropological blues (Da Matta, 1978) já prenunciava por seu caráter extraordinário, ou ainda, pelo que emerge enquanto experiência intersubjetiva do antropólogo com o Outro no exercício de seu ofício.

Além disso, havia a força do lugar de crítica cultural e de elocução que o "nativo" detinha e que forçava-nos a romper com a noção clássica de "informante" para pensarmos a relevância do diálogo (tensional; aproximativo; possível) e, nele, o seu papel de interlocutor(a) - companheiro(a) de pesquisa; pesquisador(a) nativo(a); amigo(a) - no exercício etnográfico. Na verdade não havia soluções prontas, mas uma série de problemas que devíamos enfrentar em nossas etnografias e que desde então nos perseguem em maior ou menor intensidade.

Estas considerações servem para esboçar um panorama muito sucinto em que emerge o tema da subjetividade do autor em etnografia diante das vicissitudes do trabalho de campo e das interações afetivo-intelectuais com as pessoas com as quais se convive. Sendo assim, o antropólogo na figura do narrador (Eckert e Rocha, 2005) é de fato este indivíduo que por força das tensões entre ipseidade e mesmidade (Ricoeur, 1991) de seu caráter necessita tanto uma reflexividade do si, trazendo consigo as tensões do seu tempo diante da construção e da emergência do Outro (Fabian, 1999) como sujeito epistêmico capaz de exercer um tipo de relação intersubjetiva que re-situa 
eticamente o lugar do etnógrafo, tanto no exercício da pesquisa empírica quanto na inscrição da mesma enquanto texto.

Daí que a crítica cultural na experiência etnográfica diz respeito ao si mesmo do antropólogo como sujeito ético que se questiona sobre o seu ofício, bem como à perspectiva do "nativo" - bastante relativo, para usar uma imagem de Viveiros de Castro (2002) - enquanto um ponto de vista crítico quanto à posição do antropólogo no encontro (inter)cultural e ao que se escreve acerca de sua cultura. Nestes termos, uma antropologia reversa (Wagner, 2010), onde ambos constroem as suas perspectivas acerca do outro - o antropólogo sendo o outro do outro (Silveira, 2004) - e inventam reciprocamente as culturas de ambos, coloca em jogo a dança das posições e das hermenêuticas de si e do outro, como forma de expressar a co-existência na diferença, sem com isso negar o lugar da produção de conhecimento - e, por isso, textual - do etnógrafo para lembrar o dilema apontado por Tyler (1986).

\section{Da autobiografia como possibilidade de diálogo com um leitor-Outro}

Parece-me evidente que textualizar, no sentido de inscrever e, por isso, de interpretar uma trajetória pessoal, coloca ao narrador de suas memórias a necessidade de abordar questões em torno do tema da autobiografia enquanto narrativa - ou ainda, de uma grafia da vida (Schmidt, 2004), que antes de tudo revela-se um processo de reflexividade do si que recupera lembranças, lapsos e ocasos diante da descontinuidade temporal para pensar acerca do tempo durado e seus percalços relativos a dimension intime de la vie (Lindón, 2005:58), a partir de uma tensão entre projetos e vicissitudes no vivido, como possibilidade de existir no mundo enquanto um indivíduo autônomo que exerce escolhas, sendo, por isso, afetado por elas.

Nestes termos, escapar da "ilusão biográfica" como sugere Bourdieu (1996), aponta para o fato de que antes de tomar a vida pela sua "totalidade" reveladora da unidade do eu é preciso refletir pela via do fragmentário e da descontinuidade - bem como dos erros e acertos - nos caminhos percorridos, considerando a agência de quem os trilhou. Sendo assim, por certo, as vicissitudes e as (in)coerências nos processos decisórios diante de projetos imagináveis e, mais ou menos duradouros, que se apresentam ao indivíduo mediante um campo de possibilidades, tomam forma sob a perspectiva da significação social e de sua dimensão subjetiva, levando em consideração certa margem de manobra (Schutz, 1979) e as táticas (Certeau, 1994) que o indivíduo 
elabora para si no contexto social por onde circula, estabelecendo as suas negociações e agências.

A temática do si é cara ao pensamento de Paul Ricoeur (1994), especialmente se pensarmos a autobiografia nos termos a que se refere o autor quando deixa claro, ao mencionar que na narrativa a identidade do personagem se relaciona com a transferência que é operada pela tessitura da intriga em aplicação à ação relatada. Portanto, o personagem (o si-narrativo para o caso deste artigo) se constitui ele mesmo no processo de elaboração criadora da intriga narrativa: passamos da ação à intriga e, aí, temos uma concepção narrativa da identidade pessoal. Neste sentido, a intriga permite realizar a concordância naquilo que em princípio é discordante - uma vida vivida que não é linear. A narrativa aparece enquanto um construto recíproco da ação e do si, por isso, ela jamais será neutra pelo fato de que relaciona prática e ética: ela é a constituição de si - do narrador autobiógrafo, neste caso - evidenciando a experiência e o tempo como fundamentais no processo de narrar e ficcionalizar os seus sentidos - nos termos de publicizá-los produzindo certa discursividade acerca do si-mesmo - já que a experiência pessoal é de foro íntimo (1995).

O indivíduo que conta as suas memórias pessoais possui uma inteligência narrativa com a qual atribui sentidos ao seu mundo - há um conhecimento inteligente do mesmo - que o impele a construir uma narrativa que seja inteligível ao outro, que o lê ou escuta. A intriga transposta da ação para o personagem-narrador gera a dialética do personagem, ou seja, uma dialética que é da ordem da mesmidade e da ipseidade.

É por isso que a problemática vinculada à identidade idem e a identidade ipse revela-se fundamental no pensamento de Ricoeur. Se, para o primeiro caso, a mesmidade e o idêntico - o contrário ao outro, e por isso sempre apresentando um caráter comparativo - são fatores de permanência no tempo, opondo-se a mudança e, portanto, relacionada aquilo que conforma o indivíduo uma vez que está vinculada à concordância; na identidade ipse temos o oposto, pois no caso da ipseidade a identidade não se relaciona a aspectos "não-mutantes da personalidade", porque nesse caso existe uma potência no indivíduo - o vir a ser ou o que poderá ser. O si mesmo está aberto, havendo uma espécie de virtualidade nele, que a narrativa enquanto um processo reflexivo acerca da ação, relacionada à ética, permite que se constitua como alguém detentor de uma identidade singular.

Ao elaborar as minhas memórias autobiográfcas nos termos de uma narrativa cuja intriga organiza o conjunto diverso de experiências pessoais ao longo do meu 
tempo, dando-lhes certa coerência tenho em mente que estou longe da pretensão de realizar um esboço de auto-análise nos moldes de Bourdieu (2005), mas realizo o meu exercício atento às armadilhas da discursividade autobiográfica (Bourdieu, 1996) e busco refletir sobre a importância heurística do falar - e, nesse caso, textualizar - acerca de si não como um exercício egocêntrico de pretensões narcísicas e, muito menos, como forma de denunciar o "fardo do eu" (Senett, 1988). Meu interesse reside em pensar a narrativa autobiográfica enquanto um processo de construção de si na relação com os Outros, concebendo tal dinâmica como configuradora das diversas formas sociais que expressam dimensões da subjetividade coletiva, que no âmbito deste artigo, contribuíram de diferentes maneiras para a constituição disso que sou: um indivíduo moderno.

Refletir sobre o "eu autobiográfico" é no meu ponto de vista não separar a realidade do imaginário, mas sim tomá-los como dimensões afins que se constituem mutuamente na medida em que se imbricam configurando a experiência fenomênica seja ela sutil ou densa de uma história de vida. Se, como aponta Alberti (1991:9) apoiando-se em Luiz Costa Lima o imaginário seria transgressor, penso eu que não é pela "irrealização" daquilo que toca ou pela "aniquilação das expectativas habituais" como sugere o autor, mas sim, pelo que evoca de imagens da vida vivida, mas, também, daquelas carreadas pelas memórias subterrâneas e pelo que emerge com força mediante o ato mesmo de lembrar e construir narrativamente uma intriga, que no caso da autobiografia está ligada ao espaço fantástico da memória (Eckert e Rocha, 2000) e a espessura de suas camadas (Bachelard, 1988), ou ainda, à dinâmica de um formismo que aciona complexos processos de assimilação-acomodadora de pulsões e ajustamentos de ordem objetiva e subjetiva do sujeito ao mundo diante de uma simbólica de imagens (Durand, 1989).

A intriga da narrativa diante da elasticidade e movência da memória pessoal, elaborada a partir de elementos heteróclitos e, por isso, envolvendo imagens fragmentárias do que se viveu outrora - por vezes precárias e borradas pelo esquecimento; de lembranças vívidas que rememoradas remontam fatos, aciona alegorias e exerce colagens/justaposições criativas de impressões acerca de circunstâncias vividas, sendo, desta forma, capaz de falar acerca do real de maneira à ficcionalizá-lo. Esta tensão entre real-ficcional deve ser entendida aqui como uma ação da imaginação criadora de produzir sentidos acerca do que se entende por realidade, 
mediante a experiência emocional de um indivíduo que se percebe (e, portanto, se pensa) na condição de narrador de suas memórias.

É claro, que Verena Alberti (1991) não opõe meramente a ficção ao real, pois como aponta Costa Lima citado pela autora, e mesmo, Todorov (1989), tal oposição é falsa. Se o imaginário é uma realidade como indica Maffesoli (2001) é preciso questionar a sua "irrealização" - fato ao qual Costa Lima ainda se prende. Ao opormos "o imaginário ao real, ao verdadeiro", considerando o imaginário como "uma ficção, algo sem consistência ou realidade", nos afastamos necessariamente das "construções dos espíritos" que permitem "ter um tipo de realidade na construção da realidade individual" (Maffesoli, 2001:75) e, portanto, no meu ponto de vista da própria imaginação criadora que elabora a tessitura das narrativas acerca das memórias do indivíduo que devaneia sobre as suas vivências ao longo do tempo.

Portanto, se tomarmos o imaginário pela sua potência mobilizadora de imagens que constituem o que nos acostumamos a chamar realidade, nestes termos, a imaginação criadora que re-situa o si-mesmo como outro narrativo não é apenas da ordem da transgressão, mas da própria condição do narrador como criador a realidade ficcional onde "falseamento" e "verdade" se imiscuem constituindo a intriga narrativa, onde vivido, pensado e imaginado são moedas de mesmo peso na produção imaginária da narrativa do si que pode revelar-se outro. Portanto, não se trata de opor imaginário ao significado, mas sim, enfrentar o problema da representação not in a difference between reality and its images but in a tension between re-presentetion and presence (Fabian, 1990:755).

Ora é a presença do narrador como si-mesmo e como outro, ou ainda, na copresença do si e do outro que emerge a inteligência narrativa autobiográfica como possibilidade de ser na mesmidade, enquanto concordância, e na ipseidade como um vir a ser. A dialética do personagem é a do si mesmo como um outro porque falar acerca do si mesmo é tocar no tema da outridade e, conseqüentemente, na distância presente na relação ao mesmo e ao outro, ambos produtos e reflexos da tensão entre o eu e o tu. A questão sempre é aquela que toca a problemática do Outro, uma vez que o si narrativo emerge sob a forma de um jogo discursivo onde o si revela-se outrem, mesmo quando estamos na esfera de uma grafia da vida.

Para encerrar este ponto da discussão é preciso apontar ainda o fato de que se o self para Goffman (2007) é uma questão entre o eu e o mim porque há um nós dado na interação - o self, neste caso, só pode ter relação com o eu porque existe um nós em 
relação a ele. Para Ricoeur a interação é interiorizada, pois a questão refere-se ao eu (self), mas agora, em relação ao si como oposição: o si é um pronome reflexivo que se coloca como outro, quando o "si-mesmo como um outro sugere desde o começo que a ipseidade do si-mesmo implica em um grau tão íntimo, que uma não se deixa pensar sem a outra" (Ricoeur: 1994:14).

\section{Da Biologia como vocação}

Decidi cursar Biologia muito cedo creio que por dois motivos: o primeiro dizia respeito ao meu interesse e curiosidade pela "natureza natural", nos termos de Ingold (2000), especialmente em relação aos animais e a tudo que pudesse se relacionar a sua existência enquanto seres vivos inseridos em ambientes diversos. Segundo, pelo fato de ter recebido influências de minhas duas irmãs que optaram por estudar Biologia na graduação - aliás, elas iniciaram o curso que outrora denominava-se História Natural -, portanto, cresci vendo ambas envolvidas com temas que me interessavam como aspirante àquele campo de conhecimento.

Aos 17 anos eu ingressava no curso de Biologia da Universidade do Vale do Rio dos Sinos (UNISINOS), onde meu interesse acerca dos animais tomava forma a partir de um campo de conhecimento denominado de Zoologia. Portanto, dentro de um universo tão amplo como o da Biologia eu optava por um subcampo cujas especificidades me levavam a refletir sobre as espécies animais ainda de maneira um tanto ampla.

No início do curso fiz rápidas incursões ao campo da Zoologia de Invertebrados: tentei estudar a etologia de besouros do amendoim, mas me desinteressei diante do que julguei na minha juventude a monotonia do seu comportamento; fiz incursões pelo belíssimo campo da sistemática e da ecologia de invertebrados aquáticos especialmente das formas larvais de insetos - quando realizei atividades de coleta e sistemática de bioindicadores de qualidade de água, entre eles espécies das Ordens Odonata (libélulas); Ephemeroptera (efêmeras) e Plecoptera.

No entanto, paulatinamente, voltava meus interesses para a Zoologia de Vertebrados e, mais especificamente, pelas áreas da Ornitologia (estudo das aves) e da Mastozoologia (estudo dos mamíferos), o que me conduziria por caminhos interessantes e bastante promissores na minha formação como biólogo. Quanto a esta questão posso dizer que a minha formação em Biologia seguiu um modelo tradicional, porque pautada numa abordagem bastante clássica com forte ênfase na taxonomia dos organismos vivos 
sejam eles zoológicos ou botânicos e certamente, inspirada nos naturalistas do século XIX (daí, certo viés romântico ligado a figuras como Saint-Hilaire; Martius; Humboldt ou Darwin ou, por exemplo). O naturalista e padre jesuíta Balduíno Rambo era figura inspiradora de todos e eu não era exceção - somente mais tarde saberia acerca da sua importância para a Antropologia gaúcha.

Nestes termos, a sistemática classificatória das espécies vivas - portanto, linneana - era a tônica de meus estudos e, certamente, éramos conduzidos a nos transformarmos em sistematas tanto em campos como a botânica ou como a zoologia ou seja, taxonomistas eram espécimes raros desde aquela época no país. Ou seja, ouvíamos constantemente de um de nossos professores - figura importante na Ecologia sul-riograndense - que o "Brasil precisa de sistematas!"

Éramos incitados à taxonomia, mas, obviamente, seguindo perspectivas epistemológicas que se enquadrariam dentro da chamada Biologia Moderna, claramente marcada pela influência Neodarwiniana, com forte influência da genética molecular (herdeira tanto da perspectiva darwiniana quanto mendeliana), mas, também, recebíamos influência de um campo importante como o da Ecologia - nesse caso, tanto a Sinecologia, voltada à ecologia das comunidades, quanto a Autoecologia, relacionada à ecologia de uma determinada espécie inserida na complexidade ecossistêmica, ambas as dimensões ecológicas, obviamente, consideravam os aspectos interacionais e adaptativos das espécies estudadas.

O meu ingresso como bolsista voluntário no Museu de Zoologia, entre os anos de 1984 e 1987 onde realizei inúmeras atividades laboratoriais (organização e conservação de coleções zoológicas; taxidermia; conservação do material coletado nas atividades de campo tanto no contexto gaúcho quanto da Antártida (PROANTAR); entre outras atividades) e pesquisas de campo nestas áreas do conhecimento biológico, associada aos estudos de Ecologia.

A minha formação em Biologia voltava-se aos trabalhos de campo, realizados em diversas regiões do estado do Rio Grande do Sul, mas, obviamente, se concentravam no Vale do Rio dos Sinos em locais como Picada Verão (no município de Dois Irmãos) e no complexo de Morros Areníticos da Depressão Central, mais especificamente, à porção de área situada entre os municípios de São Leopoldo (Morro do Paula) e Sapucaia do Sul (Morro de Sapucaia e Morro das Cabras), mas realizávamos campo no Parque Estadual de Itapuã; na Serra gaúcha; no Parque Nacional dos Aparados da Serra, ou na extensa costa litorânea gaúcha. 
Eu e meus colegas de curso, àquela época, estávamos interessados em aplicar os conhecimentos adquiridos na sala de aula e nas leituras que realizávamos em saídas a campo que nos possibilitassem exercer tais conhecimentos na prática. Isso nos custou alguns conflitos com professores pouco afeitos a trabalhos práticos. Muitas vezes, nós mesmos, organizávamos as nossas atividades de campo reunindo colegas que trabalhavam em diferentes áreas da Biologia - botânica; zoologia de invertebrados ou de vertebrados, entre outras áreas. Tais atividades foram fundamentais para a minha formação como profissional no que tange ao aprendizado empírico e à troca de experiências com colegas e professores ao longo do curso de graduação.

Paralelamente, realizava pesquisas em ornitologia no espaço urbano elaborando um levantamento preliminar das espécies de aves que ocorriam no bairro onde morava com minha família, na cidade de Sapucaia do Sul. Utilizava binóculo (8X30), caderneta de anotações onde registrava os dados obtidos durante as minhas saídas sistemáticas (espécie; data; tipo de ambiente e aspectos etológicos). No período registrei mais de 80 espécies de aves para o bairro.

Realizei atividades e cursos de anilhamento de aves - marcação com um anel de alumínio numerado e bandeirolas plásticas coloridas que auxiliam na identificação das rotas migratórias e no conhecimento da biologia da espécie -, censo e ecologia de aves limícolas (espécies que vivem em zonas úmidas e costeiras) e migratórias no Parque Nacional da Lagoa do Peixe e no Banhado do Taim, especialmente maçaricos, gaivotas e andorinhas do mar.

Lia avidamente autores do campo da Ecologia - entre eles Eugene Odum (1988); Roger Dajoz (1983), Ramón Margalef (1982) e Helmut Remmert (1982); o brasileiro Samuel Murgel Branco - a fim de pensar as dimensões bio-ecológicas das paisagens nas quais a avifauna que pesquisava permanecia integrada a uma ecossistêmica. Paralelamente manuseava obras de Ornitologia como a de Helmut Sick (1985) e guias de identificação de campo como os de Narosky e Yzurieta (1987) e Belton (1984), entre outros.

Quando me refiro à paisagem dentro dos estudos que realizava acerca da avifauna estou vinculando o termo à noção de ecossistema e, a partir daí à idéia de "natureza natural". Portanto, paisagem aqui significa um conjunto de componentes bióticos e abióticos em permuta de energia e matéria, engendrando uma totalidade complexa. Há uma ênfase nos componentes biofísicos, considerando a sua ciclagem biogeoquímica. 
Neste período também tentei estudar a ecologia de bugio-ruivos (Aloutta guariba clamitans) na localidade de Picada Verão sem muito êxito, especialmente, pela falta de apoio financeiro - entenda-se bolsa de iniciação científica que jamais recebi ao longo do curso e que impossibilitava a minha dedicação à pesquisa, uma vez que lecionava Ciências (e algumas vezes, Matemática) tanto na rede pública quanto na privada, para as séries que à época iam da $5^{\mathrm{a}}$ a $8^{\mathrm{a}}$, mas, também, para o Segundo Grau, onde ensinava Biologia. Em épocas de desemprego conseguia o meu sustento dando aulas particulares de Matemática, Biologia e Química, por exemplo; ou trabalhando como bolsista-empregado na universidade para financiar o meu curso de graduação.

\section{De uma Biologia pouco humanizada às inquietações acerca do lugar do humano}

O que aprendia acerca do humano tinha relação direta com disciplinas ligadas à Biomedicina, entre elas a Anatomia, a Fisiologia, a Citologia, a Histologia e a Embriologia Humanas - sempre comparativas aos não-humanos a fim de pensarmos em termos de escala evolutiva -, por exemplo. Durante as aulas em laboratórios éramos treinados na microscopia; nos estudos de anatomia mediante o manuseio de "peças" anatômicas - cortes sagitais de cabeças humanas; estudos em cadáveres e outras coisas meio mórbidas; micro-cortes e preparação de lâminas cito e histológicas, entre outras práticas. Naquele período não havia lugar para a dimensão humana nas minhas reflexões senão a partir de certo reducionismo que o compreendia pelas partes, como peças que, todavia, paradoxalmente, mediante o conceito de sistema me fazia tomá-lo como totalidade, mas, certamente, de caráter biológico. $\mathrm{O}$ organismo humano enquanto um sistema vivo estava inserido na sistêmica que ia da célula à biosfera ou desta à célula, não importando a ordem pela qual se tomasse o encadeamento sistêmico podendo-se, ainda, descer (genes) ou subir (ecosfera) mais na escala de análise.

Ao longo da minha formação em Licenciatura em Biologia, portanto, além de me interessar por pesquisas que poderiam ser chamadas de "básicas" no campo da Zoologia, voltava-me para uma área relativamente nova na década de 80, qual seja, a chamada Educação Ambiental, obviamente, que a ênfase dada era aquela relativa à conservação da natureza - começava-se paulatinamente a falar em biodiversidade, mas muito pouco em etnodiversidade. A ênfase era a da "consciência ambiental", chavão ideologizante que reduzia os saberes cotidianos a meros atos ligados a degradação, ou a saberes destituídos de maior significação naquilo que aqui poderia chamar de práticas e saberes socioambientais das pessoas em seus cotidianos, e que repetíamos ad nauseum. 
Portanto seguia dois caminhos complementares: os estudos de ornitologia e o envolvimento com a Educação Ambiental.

Ora a noção vigente à época - e diria que perdura até o contemporâneo em alguns casos - era aquela da Educação Ambiental enquanto uma proposta disciplinadora pautada em um modelo educacional conscientizador do outro visto como tabula rasa. Tal perspectiva estava ancorada na visão dos naturais como intocáveis. Sendo assim, a abordagem patrimonialista na qual as paisagens naturais de caráter cênico e de uso restrito eram entendidas como sinônimos de áreas de conservação - PARNAS; Reservas Ecológicas; Parques Estaduais, entre outros. Fui formado a partir de uma concepção que considerava o fato de que havia muito a ser dito e pouco a ouvir porque cega pelo afã de levar a consciência a esse Outro que, nesta ótica, está destituído de saberes cotidianos e ambientais. Ou ainda, se os possui são considerados preconceituosamente pelo saber acadêmico.

A Biologia é herdeira de um olhar que aqui chamarei de romântico-pragmático sobre os naturais, porque ao mesmo tempo em que detém um viés extremamente romântico de percepção e descrição das paisagens - herança dos naturalistas viajantes que têm no romantismo alemão e em Humboldt influências significativas - aliadas a um pragmatismo classificador que identifica os seres vivos como coisas que cabem na sistemática dos organismos. Portanto, mescla a visão edênica dos cronistas de viagem com o enciclopedismo descritivo e taxonômico (ligado a antiga tradição linneana), com reflexos tanto na coleta de dados em campo quanto na sua posterior análise.

Havia, por certo, um romantismo inspirado na literatura norte-americana, entre eles destacava-se Henri Thoreau - que o falecido padre Clemente, professor de botânica, nos indicava entusiasticamente a leitura -; mas eu descobriria ainda Emerson e Whitman que se por um lado evocavam o "retorno à natureza"; a poética como expressão do amor ao lugar e aos prazeres sensíveis do corpo, também indicavam caminhos como o anarquismo; os vínculos sensíveis com a terra e o amor homoerótico. Esta via de reflexão me parecia a mais interessante e me fazia paulatinamente desconfiar da discursividade que orientava a minha visão dentro do campo biológico, no meu ponto de vista extremamente rígida. Havia um potencial de transgressão na poética desses românticos que re-situava o romantismo em Biologia e a levava para uma dimensão mais humana e a via de acesso para mim era a ecologia nas suas vertentes sociais. 
No entanto, o "social" emergia nos discursos correntes enquanto uma entidade quase abstrata, descarnada das interações com os naturais, a não ser pela via de seu potencial destruidor, e a cultura, sempre no singular, referida ao Ocidente como sinônimo de letramento e acúmulo de informações, pautado no domínio dos naturais pela tecnociência. O humano figurava como signo da destruição e da poluição - a imagem do homem como câncer do planeta, como aparecia em algumas críticas radicais, por interagir com a natureza sempre a partir de uma visão de substrato para a produção de bens de consumo.

Se por um lado eu seguia com os estudos ornitológicos e o meu interesse por educação ambiental, por outro, diante das leituras que autores da Ecologia Social e Política suscitavam - entre eles Murray Bookchim; Lewis Mumford; Ivan Illich (1976), Ray Dasman, René Dubos (1981), Jean Dorst (1973), Jean-Pierre Dupuy (1980), entre outros - ampliava a minha perspectiva. Também me interessava pelos autores brasileiros, como o precursor do ambientalismo gaúcho que vivera no Vale dos Sinos (e, certamente, um dos primeiros no contexto nacional), Henrique Roessler, mas havia também José Lutzemberger, Sebastião Pinheiro e Flávio Lewgoy, por exemplo, ligados a AGAPAN.

A partir daí redimensionava os meus interesses sobre o humano inserido no mundo, cuja presença fortemente dicotomizada pela oposição excludente entre natureza e cultura, era vista como perversa porque devastadora, figurando na imagem "do homem que destrói a natureza" versus o homem reencantado que se preocupa com a ecologia e protege a natureza. Naquela época a minha perspectiva centrava-se na crítica ao sistema capitalista e as suas mazelas ambientais, mas não tinha maiores convicções em termos de que posicionamento tomar em relação às tensões existentes entre o preservacionismo - visão, no meu ponto de vista, sempre hegemônica e voltada para "o mito da natureza intocada", como Diegues (1994) apontaria mais tarde - e o conservacionismo, mais pragmático e mais parcimonioso às experiências humanas no mundo.

Se naquele período renovava os meus interesses pela ornitologia realizando visitas a campo sistematicamente, mais especificamente aos Morros Areníticos da Depressão Central, não podia dizer o mesmo do curso de Biologia que se tornava cada vez mais desinteressante pelo excessivo reducionismo que me incomodava e pelo que aos poucos começava a me aborrecer - a imagem generalizadora do "homem" como degradador e destruidor dos naturais. 
As idéias de "impacto ou da ação antrópica", que se por um lado poderia indicar problemas palpáveis de um mundo ocidental que vivenciava uma franca globalização dos conflitos ambientais - que paulatinamente se transformavam em "socioambientais" -, por outro me colocava num lugar tranqüilo para a crítica a esse homem devastador, mas tais idéias revelavam-se expressões que pareciam vazias porque jogavam a dimensão humana, que intuitivamente se apresentava para mim como diversa, no mesmo balaio de gatos.

Quando em 1986 realizei um curso de anilhamento e de censo de aves limícolas no PARNA da Lagoa do Peixe, situado em Mostardas (RS), senti na pele o que se configurava como um dos dilemas recorrentes nos conflitos socioambientais: por um lado os pesquisadores imbuídos de boas intenções na preservação das espécies migratórias ou não; de outro os fazendeiros e plantadores de cebola enfurecidos com a Unidade de Conservação recém criada, o que nos fazia temer represálias e tiros perdidos ao sairmos da base de pesquisa; e, finalmente, os moradores e pescadores locais extremamente aflitos com a possibilidade de serem retirados da área em que viviam e manejavam havia anos. A partir de então a minha perspectiva diante dos "humanos" desde o campo da Biologia começou a mudar senão de toda, pelo menos algumas questões passaram a me perturbar - e creio que vários colegas meus sequer pensavam nela -, entre elas a que dizia respeito ao fato de que as pessoas deveriam permanecer nas áreas de preservação de espécies ameaçadas de extinção? O que a biologia da conservação negava em relação às experiências dos grupos humanos com os lugares que viviam desde longas datas e cujos vínculos sequer eram considerados?

Em 1987 fui morar na casa do estudante de São Leopoldo e passei a me envolver com atividades que extrapolavam os meus interesses em Biologia, que nestas alturas perdia o encanto pelo que julgava como um reducionismo sem alma por não ver as pessoas, mas também pela falta de incentivo e as dificuldades que enfrentava para realizar atividades de pesquisa. Naquela época já havia tido uma rápida passagem pelo teatro - mas a minha timidez me tornava pouco apto ao exercício do ator; e no período escrevia poesias compulsivamente - pensei em cursar História ou Jornalismo, mas já estava bastante envolvido com a Biologia para desistir.

O movimento estudantil, meio moribundo, experimentava um ressurgimento e me engajei a luta contra o aumento das mensalidades na universidade, mas logo aquele ranço militante me pareceu conter uma dose excessiva de interesses duvidosos, machismos e homofobia - os discursos "revolucionários" na verdade eram bem 
reacionários - e me afastei (nessas alturas o livro de Cornelius Castoriadis e Daniel Cohn-Bendit (1981); as provocações anarquistas de Bookchin e de André Gorz que lia na época em edições espanholas e A Contestação Homossexual, de Guy Hocquenghem (1980) me seduziam muito mais.

A partir do convívio com amigos, principalmente, dos cursos de Jornalismo, Publicidade e Propaganda, Ciências Sociais, Psicologia e Direito passei ampliar o meu leque de interesses - estética pós-punk; arte contemporânea; psicodelismo; literatura marginal; ecologia social e política; anarquismo; entre outras coisas que me atraíam desde o início dos oitenta. Todavia o fantasma da AIDS nos atropelou como um signo do estigma que nos arrebatou, assaltando de surpresa um processo de intensas descobertas e vivências tanto pessoais quanto afetivo-sexuais.

Meu descontentamento com o que julgava extremamente redutor na Biologia levou-me a ingressar no Laboratório de Edafologia e Vermicompostagem sob orientação da bióloga e ecóloga humana Christa Knapper, afinal de contas nada melhor do que pensar o solo como um organismo vivo na sua relação com as práticas humanas ligadas ao seu manejo. Neste período trabalhei intensamente em Educação Ambiental elaborando textos e realizando práticas educativas junto às escolas no Vale dos Sinos, inserido num grupo bastante criativo. Éramos mal-vistos por alguns colegas porque taxados de biólogos mais interessados pelos humanos do que pelos bichos e plantas, no entanto, participávamos de um grupo interdisciplinar que buscava ampliar o sentido das relações entre humanos e natureza a partir de questões edafológicas práticas. Quanto à ornitologia seguia realizando as minhas saídas a campo para realizar o levantamento da avifauna dos morros areníticos.

As trocas de saberes e influências estéticas com colegas e amigos me conduziam por caminhos pelos quais aliava o que vivia no plano das experiências ligadas a certo tribalismo que vivia com meus amigos, pois as atividades de levantamento da avifauna que realizava estavam associadas à fruição estética de estar em contato com os naturais, por vezes, com tais pessoas. Havia à época um movimento meio marginal que alguns chamavam de neobucolismo relacionado a uma estética romântica de enlace com as paisagens e de querer estar em contato com elas. Vivíamos a fruição da natureza ao mesmo tempo em que estávamos interessados em expansão da consciência. 


\section{Mudanças de perspectivas}

Terminei o curso de Biologia em 1990 e apresentei como monografia de final de curso uma pesquisa envolvendo o levantamento da avifauna livre dos morros areníticos do município de Sapucaia do Sul. Logo segui para Pernambuco onde realizei treinamento em censo e anilhamento de aves limícolas na Coroa do Avião, nas proximidades da Ilha de Itamaracá, onde permaneci por dois ou três meses vivendo na Base de Pesquisas do Projeto ligado a Universidade Federal Rural de Pernambuco (UFRPE).

Foi a minha última tentativa de continuar trabalhando com ornitologia. De volta ao Rio Grande do Sul ingressei no curso de especialização em Ecologia Humana (UNISINOS), obviamente com meia bolsa que consegui graças ao apoio de pessoas que conhecia na instituição e retomei tanto algumas atividades junto ao Laboratório de Edafologia quanto à docência na rede municipal de ensino, enquanto realizava o curso entre os anos de 1992 a 1993.

Na virada dos anos 80 para os 90 encontro uma série de autores e abordagens que me instigam e, de certa forma, me colocam num certo limbo entre a Biologia e perspectivas, diria, mais humanísticas que focavam na idéia de mudança de paradigma na ciência, questões ligadas à epistemologia. Se, desconfio um pouco disso hoje, na época tal literatura foi relevante para reencontrar o tema da cibernética, do holon e da imagem sistêmica do todo envolvendo uma sinergística, que se não descambava para a New Age pelo menos abria perspectivas de produção de um conhecimento mais integrado e menos fragmentado.

No entanto, leituras sobre cibernética me conduzem a autores como Edgar Morin - O paradigma perdido teve um grande impacto sobre mim -, Henri Atlan e Ilya Prigogine; descubro biólogos mais interessantes como Gregory Bateson - que somente depois descobriria ser também antropólogo -; Humberto Maturana e Francisco Varela; James Lovelock; Rupert Sheldrake e, é claro, o autor da moda naquele período, Fritjof Capra. Se o Tao da Física chamara a minha atenção pelo inusitado do paralelismo entre Física Quântica e Taoísmo, nada me tocara mais do que o seu livro de entrevistas denominado Sabedoria Incomum. É claro que havia a produção de José Lutzemberger (1990) e de Samuel Murgel Branco (1999) que traziam tais questões a partir de um olhar desde o Brasil.

Meus interesses a partir de 1992 estavam voltados ao tema da cidade. A Ecologia Humana que estudava era totalmente relacionada às problemáticas 
socioambientais e a gestão dos recursos naturais. A Eco 92, no Rio de Janeiro, colocara o tema da biodiversidade como a tônica dos discursos preservacionistas/conservacionistas, bem como a destruição da camada de ozônio e os problemas urbanos no centro das questões, onde os recursos hídricos se destacavam. Neste sentido, os debates giravam em torno das formas alternativas de produção energética; de temas de conservação e legislação ambiental; de estratégias para reduzir a poluição urbana; da gestão ambiental, entre outras questões.

Durante o curso uma das disciplinas que cursei fora ministrada por um jovem antropólogo - Marcio Pizarro Noronha - com o qual me identifiquei tanto pela abordagem antropológica quanto pela forma como trabalhava a questão do humano no contexto das problemáticas socioambientais. Bom, finalmente encontrara uma abordagem mais próxima do que queria, todavia, ainda tinha uma visão da Antropologia muito estereotipada e pouco clara. Na medida em que fui me aproximando do campo antropológico fui revendo meu ponto de vista acerca de uma série de questões, mas não sabia bem onde isso me levaria.

Os autores que lia naquele momento e as minhas experiências estéticoanarquistas anteriores me faziam romper com a figura do "homem urbano" devastador em si mesmo; mas havia certa ingenuidade no meu olhar que tendia a perceber o indígena pela imagem do bom selvagem quiçá do índio hiper-real como apontou Alcida Ramos; os seringueiros - encarnados na figura emblemática de Chico Mendes desdobrados na imagem da tradição cristalizada e aí, a paisagem como consequência de uma harmonia do homem com a natureza. A Amazônia e sua floresta reinavam como paraíso terreal distante a ser protegido. Nunca imaginaria que anos mais tarde viria a morar e trabalhar nesta mesma Amazônia distante e que teria amigos e companheiros de atividades junto ao Conselho Nacional dos Seringueiros (CNS) instituição que Chico Mendes ajudara a construir.

Meu contato com a Antropologia, se não me afastou da Ecologia alavancou meu distanciamento da Ornitologia e da Zoologia de forma geral. Um dos primeiros impactos que sinto diante da minha inserção no campo antropológico é o de que a natureza antes de estar fenomenicamente circunscrita a sua materialidade é uma construção cultural, podendo variar de acordo com o grupo humano que lhe atribui sentidos. Ora, até então, a natureza era essa interação entre o biótico e o abiótico e seus ciclos complexos. Não havia para mim a possibilidade de pensá-la de outra forma. Isso de alguma maneira alterou a minha maneira de ver tanto "os naturais" quanto os grupos 
humanos que com eles co-existiam em interações de diversas ordens e que, por certo, transcendiam, a mera sobrevivência. Há uma desconstrução de uma visão de mundo legitimada pelo campo da Biologia enquanto verdade: passo a vê-la, a partir daí, como uma possibilidade de interpretação do mundo.

Diante dos conflitos socioambientais ligados às áreas de conservação começo a me afastar dos resquícios de uma postura radical em relação à dimensão humana, relacionada aos dilemas da preservação das espécies ameaçadas de extinção. Mudo o foco do meu interesse da Zoologia para a Antropologia, todavia, considero a Ecologia como campo de interesse porque dinâmica e menos reducionista, portanto, aberta ao diálogo interdisciplinar. Desloco, então, o meu interesse para questões relativas às representações de natureza, principalmente à medida que vou estabelecendo os primeiros contatos com as pesquisas etnográficas. Neste momento conheço Margarete Fagundes Nunes, que concluía o curso de Ciências Sociais na UNISINOS sob orientação de Marcio. Somos, eu e ela, incentivados por ele a elaborarmos projetos para a seleção no Mestrado em Antropologia Social na Universidade Federal de Santa Catarina (UFSC).

\section{Da Biologia à Antropologia, ou da avifauna aos ecoturistas}

Como uma tática para eu conhecer um pouco do universo dos antropólogos e a universidade poderia vir a estudar decidi participar da ABA - Sul em Florianópolis, em 1993. Para tanto submeti um trabalho sobre percepções das paisagens dos morros areníticos da Depressão Central. Para a minha alegria o trabalho foi aceito.

Após a apresentação do trabalho a coordenadora do GT no qual participava como apresentador elogiou a proposta e sugeriu que eu fizesse a seleção para o mestrado na UFSC. Fiquei meio perplexo com a sua indicação porque até então queria fazê-lo, mas, sinceramente, por ser biólogo julgava algo distante. A sua colocação junto àquelas de meus amigos serviram de estímulo para seguir nos estudos e na elaboração do projeto de pesquisa visando à seleção do mestrado. Elaborei um projeto de pesquisa sobre representações de natureza entre ecoturistas na Ilha de Santa Catarina e fui aprovado na seleção, assim como Margarete, que pesquisaria junto ao grupo Olodum, em Salvador (BA). Ambos fomos orientados por Carmen Rial.

$\mathrm{Na}$ época havia feito concurso para o magistério estadual em Sapucaia do Sul, no entanto, não titubeei diante da oportunidade de estudar antropologia. Pedi demissão do emprego e segui para Florianópolis, obviamente, com o dinheiro contado e torcendo 
para ganhar uma bolsa de mestrado. Fui contemplado com uma bolsa da CAPES e pude realizar o curso.

Estudei as práticas de turismo de aventura e de ecoturismo entre as camadas médias urbanas na Ilha de Santa Catarina. A partir da pesquisa etnográfica buscava compreender as representações de natureza que relacionavam aventura, esporte e lazer à fruição entre os naturais. Procurei compreender o fenômeno do ecoturismo ligando-o ao tema da viagem e da evasão do lugar de origem, surgindo assim, a figura simmeliana do estrangeiro, mas, também enquanto um continuum que ligava viajantes (entre eles os conquistadores) naturalistas, turistas (remetendo, inclusive, a Grand Tour) e, finalmente, os ecoturistas como aventureiros que se lançam aos exotismos presentes nas relações com as paisagens.

A perspectiva apontada por DaMatta (1993) de que a ecologia emerge no contemporâneo como metáfora de natureza foi importante para refletir acerca das formas pelas quais os naturais eram percebidos e interpretados entre os grupos urbanos que praticavam turismo de aventura e ecoturismo junto às paisagens da Ilha de Santa Catarina. Tal questão apontava para o complexo jogo entre naturalização da cultura e culturalização da natureza presente no contemporâneo, diante das diversas formas de dos coletivos humanos estabelecerem relações e enlaces diversos entre cultura e natureza, agora, como oposições binárias includentes e complementares. Nestes termos, a questão residia em reposicionar o lugar de ambas nesta relação escapando de antagonismos excludentes que tomam a cultura como apartada da natureza, ou a natureza como dimensão do mundo material e fenomênico inferiorizada pela cultura.

Durante o mestrado em Florianópolis morei na Praia do Campeche onde convivia com vários colegas - Margarete, Ledson, Maria Lúcia - grande amiga, recém falecida e que deixou saudade -, Cristina, além de outros colegas da UFSC e da UFRGS (especialmente, Rogério Rosa) que freqüentavam nossas casas. Esse grupo, além de compartilhar do cotidiano da vida na ilha, constituía um núcleo de reflexão e de estudo no campo da antropologia com o qual aprendi muito e que ficou conhecido como Comunidade do Campeche. Este pequeno grupo me auxiliou enormemente a entrar no universo conceitual da Antropologia e a operar este arcabouço conceitual novo para um biólogo que se arriscava numa seara que não era a sua. Além desse grupo vivia no Campeche uma das pessoas que mais admiro na antropologia brasileira e que foi meu professor de Método de Pesquisa, o meu querido amigo Helio Raymundo dos Santos 
Silva. Defendi a dissertação em setembro de 1996 e estavam na minha banca Helio Silva e Cornelia Eckert que viria, posteriormente, ser minha orientadora no doutorado.

\section{Retorno ao Rio Grande do Sul e o trabalho no Terceiro Setor}

Logo que retornei ao Rio Grande do Sul fui convidado por Ana Luiza e Cornelia a integrar o Instituto Anthropos, Organização não Governamental voltada às ações e reflexões centradas no tema dos recursos hídricos e das problemáticas socioambientais presentes no mundo urbano, com forte ênfase em trabalhos relacionados às aprendizagens ambientais. Os projetos propostos pelo grupo eram elaborados por uma equipe interdisciplinar - engenheiros sanitaristas; economista; jornalista; biólogo; antropólogos; socióloga, advogada, entre outros que passaram pela equipe ao longo dos anos que permaneci atuando mais intensamente junto ao grupo de 1996 a 2004. Não obstante o fato de atualmente morar em Belém (PA), continuo ligado ao Instituto.

Àquela época, apesar da acolhida, o final do ano de 96 e o ano de 1997 constituíram-se num período difícil para mim devido ao fato de não ter um emprego fixo - o que me causava certa frustração, pois era um mestre em Antropologia desempregado -, daí a necessidade de realizar algumas atividades esparsas para me manter, de qualquer forma em 97 cooperei com o curso de Especialização em Urbanismo na ULBRA e realizei algumas palestras em universidades sobre a minha dissertação, bem como algumas consultorias que surgiam através das atividades no Instituto Anthropos.

A experiência junto ao grupo contribuía (e contribui, obviamente, até hoje) para ampliar a minha perspectiva acerca dos naturais e do lugar do humano nas interações com eles. O que ocorria era uma reorientação paulatina do conceito de natureza que iniciara no mestrado e o encontro com os temas das paisagens, do imaginário, da memória e da narrativa que surgiam a partir de nossas reflexões interdisciplinares quanto às problemáticas socioambientais que nos deparávamos no sul do Brasil (mas, também, em outras partes do país onde atuávamos), as quais teria condições de aprofundar mais tarde, quando me concentraria em questões relativas a outro contexto sul-riograndense, na minha pesquisa de doutorado.

O período que atuei mais intensamente no Instituto Anthropos foi de grande importância para a minha formação profissional e intelectual, pois adquiri experiência significativa quanto à elaboração de projetos na área socioambiental voltados à temática da água, especialmente no âmbito das aprendizagens ambientais, bem como, ampliei o 
meu leque de reflexões no campo da Antropologia sem com isso me afastar tanto da Biologia quanto da Ecologia.

É preciso salientar que realizávamos críticas a um determinado modelo didáticopedagógico que julgávamos problemático por desconsiderar aspectos sócio-culturais relevantes para o campo antropológico no que tange às complexas relações entre cultura e natureza no Brasil, excessivamente centrado na conduta de levar a consciência ao Outro sem exercer a escuta de suas vivências e, por isso, a dialogia. Para nós era necessário (re)pensar as tensões inerentes ao campo ambiental o que implicava questionar alguns aspectos acerca da educação ambiental que vislumbrávamos no cenário didático-pedagógico à época - e que, no meu ponto de vista, passados tantos anos, percebo que em 2011 pouca coisa mudou.

Por outro lado em termos pedagógicos havia problemas quanto às questões de ensino-aprendizagem que eu entendia estar excessivamente centradas no que Brügger (1994) denominou de "adestramento ambiental". Além disso, o trabalho em equipe, de caráter interdisciplinar, gerava debates calorosos e ricos pelo cruzamento de perspectivas e saberes diversos, tanto na elaboração de um conhecimento em comum (os projetos) quanto na sua execução, acerca das problemáticas urbanas relativas à água ou a outro tema ligado as questões socioambientais no mundo urbano. Escrevi um artigo em 1999, republicado dez anos depois como capítulo de um livro contendo algumas pequenas alterações, que tocava nestes temas e que até hoje, penso, ainda traz consigo uma crítica importante a forma corrente de pensar as aprendizagens ambientais, gestada desde a minha inserção no Instituto.

Entre os anos de 1998 e 2000 lecionei numa universidade do interior do Estado. Foi a partir desta experiência de conviver com a realidade dos grupos sociais que moram numa região situada nas proximidades das Missões gaúchas, que resolvi elaborar um projeto de pesquisa visando à realização da seleção para o doutorado em Antropologia Social na UFRGS. A proposta era a de tentar compreender as relações entre os moradores da região missioneira com as suas paisagens de pertença, através de uma pesquisa que articulasse a memória e o imaginário, e que me possibilitasse compreender os seus vínculos simbólico-afetivos com as paisagens mediante as narrativas que abordassem três aspectos relevantes de suas experiências com os lugares praticados: 1) as narrativas de trabalho, considerando a manutenção das roças e as lidas com o gado; 2) as narrativas sobre visagens e assombrações e, 3) as narrativas de guerrilhas e de revoltas campeiras, ocorridas na região desde o XVIII. 
Realizei o doutoramento entre os anos de 2000 a 2004. Permaneci nas Missões, me estabelecendo no município de São Miguel das Missões por cerca de um ano (entre 2001 e 2002), quando realizei intensa pesquisa de campo por uma vasta área na qual se distribuíam outrora os Sete Povos das Missões. A etnografia nas Missões foi possível porque construí relações de amizade e de parceria com as pessoas que convivi, de maneira que todo o período que permaneci na região interagi com muitos missioneiros, o que me possibilitou realizar um trabalho de campo que teve como marca tanto a hospitalidade missioneira quanto a abertura ao diálogo comigo; a intensa mobilidade pelos diversos locais percorrendo as redes sociais de meus companheiros de aventura etnográfica - especialmente a família Santos; seu Frutuoso, entre outros.

Foi uma experiência enriquecedora em termos pessoais e intelectuais que resultou em minha tese de doutorado, denominada Paisagens fantásticas $e$ o barroquismo das imagens. Estudo da memória coletiva dos contadores de causos da região missioneira do Rio Grande do Sul.

A tese trazia mudanças significativas na minha forma de pensar até então acerca das paisagens. Eu abandonava as noções de paisagem natural e de paisagem cultural, extremamente dicotomizantes e, por isso, reveladoras de certa oposição excludente entre cultura e natureza. A noção de paisagem era substituída, como sugeria Sansot (1983), pela de paisagens, por se tratar de um fenômeno plural que antes de excluir o humano da cena, figurando como observador externo incluía-o desde a sua percepção do meio, mas, também, desde a sua integração-ação nele, apontando para o que Ingold (2000) chama de engajamento.

Portanto, as paisagens seriam meio porque decorrentes das interações entre humanos detentores de expressões culturais diversas e os ambientes ecológicos (natureza natural) - considerando as suas simbólicas acerca dos naturais e, assim, do que chamava na tese de dimensões biogeocósmicas - capazes de engendrar hermenêuticas das paisagens, definidoras, por um lado, das ações e dos manejos sobre os ambientes até certo ponto particulares e, por outro, das influências exercidas sobre e junto aos grupos que indicam adaptações de caráter cognitivo e sensível tanto a ordem de uma ecossistêmica quanto aquela do imaginário. A noção de recursividade como aparece em Maturana (1992), ou a de duplo-vínculo, de Bateson (1986) são importantes para as minhas reflexões.

Ficava claro para mim, especialmente, pela influência da abordagem do cubano José Lezama Lima (1988), que ao dizer paisagens eu estava me remetendo diretamente 
ao âmbito das expressões culturais em consonância com os naturais, pois se existem culturas no mundo ocorrem paisagens distintas, uma vez que a diversidade de uma está intimamente relacionada à da outra, tanto em termos formais - e, por isso, simmelianos - no sentido de conformação das paisagens quanto em termos ecossistêmicos e de vínculos simbólico-afetivos estabelecidos com elas, no sentido da configuração, ou ainda, num figurar juntos.

É neste sentido que o lugar de pertença é fundamental na complexa emergência das paisagens como processos dinâmicos de engajamento do humano aos lugares praticados (Certeau, 1994) a partir do seu gênio criativo - a sua imaginação criadora nos termos bachelardianos - envolvendo certa adesão a regimes de imagens e a produção de imaginários, onde imagens convergem e constelam em determinados lugares (Durand, 1989), ligadas a força das memórias individuais e coletivas (Halbwachs, 1990), bem como aos seus "jogos" que remetem às auras das paisagens, constituindo, assim, camadas e definindo toponímias, podendo emergir sob a forma de narrativas cujas intrigas dizem respeito ao caráter fabulatório dos narradores.

A elasticidade e o trabalho da memória (Rocha e Eckert, 2000; Bosi, 1994) são, assim, formas de acessar a sua dimensão labiríntica e complexa, seus meandros sensíveis ou terrificantes. As paisagens, portanto, seriam rememoradas quando se processa o ato narrativo relacionado ao exercício criativo de elaborar a intriga narrativa (Ricoeur, 1994) e suas tramas, espécie de tessitura sutil elaborada por lembranças e esquecimentos, fluidez e hesitação; poética e imagética. Tais paisagens narradas estão desta forma, situadas no espaço-tempo de outrora, contrastadas com as paisagens nas suas feições contemporâneas.

Ora, nestes termos, a memória do lugar e não o lugar da memória, como aponta Nora (1989), assumia maior relevância para as questões que buscava compreender. As memórias locais entranhadas nas paisagens e nas suas constelações de imagens (laborais; afetivas; terrificantes) constituíam importantes elementos de sua aura, o que permitia que acessasse as camadas profundas das memórias relativas às experiências missioneiras no mundo a partir das fabulações dos seus habitantes e dos personagens que compunham comigo a etnografia enquanto experiência compartilhada porque vivida, mas, também, textual. 


\section{De São Luís à Belém}

Defendi a tese em fevereiro de 2004 e um mês depois já estava morando em São Luis, no Maranhão. Permaneci na capital maranhense durante um ano e meio, quando lecionei numa faculdade particular para diversos cursos de graduação: Turismo, Jornalismo, Publicidade e Propaganda Administração de Empresas, entre outros. Como tenho formação interdisciplinar ministrei disciplinas bastante diversas, o que me fez adquirir uma grande experiência no que se refere a operar com conceitos de campos diversos, como os da Antropologia; da Semiótica; da Ecologia; da Gestão Ambiental e do Turismo e assim por diante.

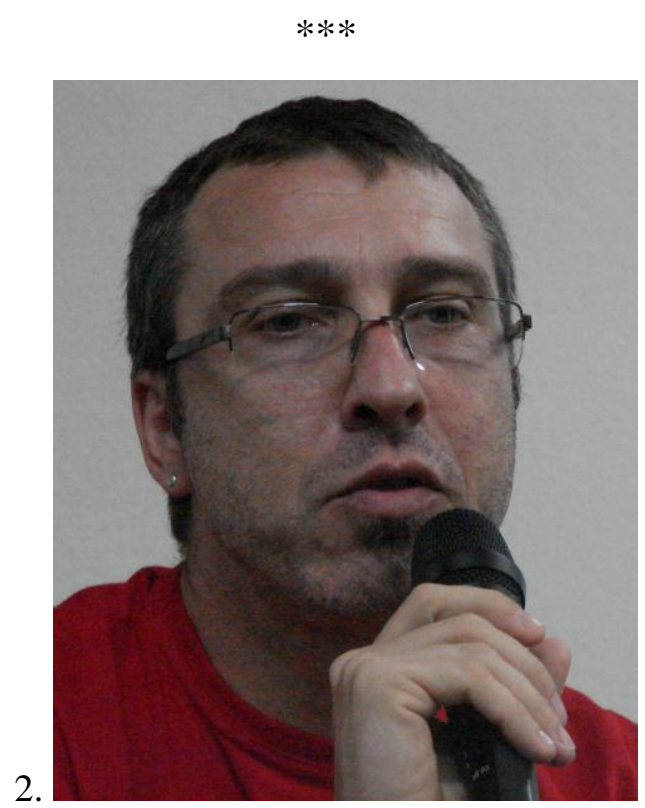

Prof. Flávio Leonel da Silveira. Foto de 03 dezembro 2010. Conferência no II Colóquio Individualismo, Sociabilidade e Memória. Sala Pantheon IFCH UFRGS. Acervo BIEV PPGAS IFCH UFRGS.

Foi um período de muito trabalho em sala de aula e de aprendizado em relação ao universo cultural maranhense. Conheci várias regiões do estado, especialmente a partir das atividades que desenvolvia como meus colegas e alunos do curso de Turismo.

Durante o período que permaneci na ilha de São Luis atravessei por diversas vezes às águas revoltas da Baía de São Marcos para chegar à cidade histórica de Alcântara, onde além de realizar algumas observações etnográficas, desenvolvi atividades de Educação Patrimonial e Ambiental em parceria com uma ONG local situada na Praia do Barco, chamada OCA (Oficina de Comunicação e Arte). Desenvolvemos atividades junto aos professores de ensino fundamental visando à 
discussão sobre a conservação do patrimônio sociambiental ligado às fontes e poços de água, alguns deles datando do século XVIII, com apoio do IPHAN.

No final do primeiro semestre de 2005 realizei concurso para professor de $3^{\circ}$ grau na Universidade Federal do Pará (UFPA), tendo sido aprovado. Desta forma, cerca de dois meses após o concurso fui nomeado e, desde então, estou lotado na Faculdade de Ciências Sociais do Instituto de Filosofia e Ciências Humanas (IFCH) desta instituição. Desde 2006 tenho realizado pesquisas etnográficas junto aos meus orientandos de PIBIC e de pós-graduação (mestrado e doutorado) no mundo urbano de Belém, centrando as minhas pesquisas no campo da memória e do imaginário a fim de compreender as relações dos seus moradores com as paisagens - sejam elas fantásticas ou não -, no âmbito do projeto intitulado Paisagens, memória coletiva e trajetórias sociais. Estudo antropológico das fronteiras culturais no mundo urbano contemporâneo na cidade de Belém - PA, dentro do qual venho elaborando outros projetos menores.

Este projeto de pesquisa visa dar continuidade aos meus estudos de doutorado, obviamente, mudando o enfoque para o contexto urbano de uma cidade na zona equatorial brasileira, com outras características de ocupação do espaço; de práticas socioambientais e de conformação paisagística no corpo da civilização brasileira. $\mathrm{O}$ projeto, portanto, se volta para as relações dos belemenses com as suas paisagens de pertença a partir das relações dos moradores de bairros mais antigos (Batista Campos; Campina; Cidade Velha e Reduto), bem como de pessoas que exercem ofícios que poderíamos chamar, por falta de palavra melhor, tradicionais, tais como: barbeiros; sapateiros, costureiras e taxistas.

Como a ênfase da pesquisa está centrada nas transformações das paisagens urbanas experienciadas pelos seus habitantes ao longo dos anos, tenho interesse além das reflexões acerca dos ofícios de trabalho, nas memórias relativas à destruição/reconfiguração paisagística da urbe considerando a presença tanto das entidades culturais imaginárias, nos termos de Lezama Lima (1988), como as assombrações e as visagens, quanto à presença das paisagens ruiniformes no corpo da metrópole, com influência simmeliana (1935).

Neste sentido, o sub-projeto intitulado Paisagens ruiniformes e os labirintos da memória na cidade de Belém (PA): dinâmicas temporais, transformações dos espaços e imaginários urbanos, reúne estas preocupações e dá continuidade as interesses de pesquisa que venho desenvolvendo desde 2000 - e, neste caso, voltando o empenho 
para o tema da ruína como receptáculo de memórias e imaginários acerca da cidade tensionando lembranças e esquecimentos. Vários artigos apareceram nos últimos anos em publicações minhas e conjuntas com orientandos em revistas de circulação regional e nacional sobre tais questões e outros devem aparecer.

No momento, além destes interesses de pesquisa, desenvolvo um projeto que, se por um lado se insere dentro da proposta do projeto maior, por outro avança em questões relativas ao mundo urbano belemense, na medida em que se propõe a pensar as interações entre humanos e não-humanos no espaço citadino e suas implicações com as paisagens de pertença. Trata-se do projeto Estudo antropológico das interações de humanos com os não-humanos no Bosque Rodrigues Alves na cidade de Belém (PA). Paisagens de evasão, conservação da biodiversidade e imaginário urbano. Aqui, novamente, o tema da memória - agora, com uma dimensão ambiental -; das paisagens de pertença - reunindo patrimônios bioculturais - e das ruínas, uma vez que o Bosque enquanto construto oriundo da Belle Epoque paraense apresenta ruínas "construídas" dentro de uma idéia de paisagem romântica.

Participo do projeto coordenado pela arqueóloga Márcia Bezerra de Almeida denominado Os Significados do Patrimônio Arqueológico para os Moradores da Vila de Joanes, Ilha de Marajó, Brasil, onde tentamos compreender as relações dos moradores da pequena vila com os artefatos arqueológicos coletados por eles e suas relações tanto com as paisagens (ruiniformes, inclusive) quanto com a memória local acerca do passado e dos seres fantásticos que habitam tais paisagens e animam o imaginário naquele contexto marajoara.

Paralelamente, realizei pesquisas sobre sexualidade entre indígenas do Matogrosso do Sul, mais especificamente entre as etnias Guarani (Nhandeva e Kaiowá) e Terena, que vivem nas aldeias Jaguapiru e Bororó nas proximidades da cidade de Dourados, no âmbito do projeto intitulado Sexualidade e conjugalidade entre pessoas do mesmo sexo na aldeia e na cidade, cuja proposta era a de discutir a trajetória de pessoas e de casais quanto à construção e à percepção de relacionamentos com pessoas do mesmo sexo e a configuração do que chamamos de suas paisagens do desejo, pensando a questão a partir do campo da antropologia urbana, por tratar-se de indígenas que vivem no contexto citadino ou nas suas proximidades. No momento, trabalho os dados da segunda temporada de campo, a fim de elaborar novos artigos.

Ainda, no âmbito de projetos fora do contexto paraense, participo com minha colega Edna Alencar do projeto Ocupação humana e dinâmicas territoriais na região 
do Japurá-Maraã, RDSs Amanã e Mamirauá, AM, cuja tônica é a de compreender a dinâmica do deslocamento das comunidades ribeirinhas, considerando as memórias relativas à ocupação dos territórios.

Finalmente, preciso deixar claro que desde que cheguei à Amazônia tenho orientado sistematicamente alunos de PIBIC, de mestrado e doutorado nos Programas de Saúde e Sociedade; Ciências Sociais e Antropologia, em diversos temas diretamente relacionados aos meus interesses de pesquisa, mas, também, acerca de temas pelos quais tenho ampliado os meus interesses. Agradeço a todos eles pela oportunidade de aprender com os seus trabalhos e de colaborar em suas pesquisas, tanto em suas investigações de campo, quando isso é possível, quanto nos seus vôos intelectuais.

\section{Referências}

ALBERTI, V. Literatura e autobiografia: a questão do sujeito na narrativa. In: Estudos Históricos, 7(4). Rio de Janeiro: CPDOC/FGV, 1991. p. 66-71.

BACHELARD, G. A Dialética da Duração. São Paulo: Ática, 1988.

BATESON, G. Mente e Natureza. A Unidade Necessária. Rio de Janeiro: Francisco Alves, 1986.

BATESON, G. "Os homens são como planta. A metáfora e o universo do processo mental”. In: THOMPSON, W. I. Gaia uma teoria do conhecimento. São Paulo: Gaia, 1990.

BELTON, W. Aves Silvestres do Rio Grande do Sul. Porto Alegre: FZB, 1984.

BOSI, E. Memória e Sociedade. Lembranças de Velhos. São Paulo: Companhia das Letras, 1994.

BOURDIEU, P. “A ilusão biográfica”. In: FERREIRA, M. de M. E AMADO, J. (orgs.). Usos \& abusos da História Oral. Rio de Janeiro: Ed. da Fundação Getúlio Vargas, 1996. p. 183-91.

BOURDIEU, P. Esboço de auto-análise. São Paulo: Companhia das Letras, 2005.

BRANCO, S. M. Ecossistêmica. São Paulo: Edgard Blucher, 1999.

BRÜGGER, P. Educação ou adestramento ambiental? Florianópolis: Letras Contemporâneas, 1994.

CALDEIRA, T. P do R. "A presença do autor e a pós-modernidade na antropologia". In: Novos Estudos CEBRAP. São Paulo: Cebrap, 1988.

CAPRA, F. Sabedoria Incomum. Conversas com pessoas notáveis. São Paulo: Cultrix, 1997.

CARDOSO de OLIVEIRA, R. "A Categoria de (Des) Ordem e a Pós-Modernidade na Antropologia". In: Anuário Antropológico. Rio de janeiro: Tempo Brasileiro/UnB, 1986. p. 57-73.

CASTORIADIS, C. \& COHN-BENDIT, D. Da ecologia à autonomia. São Paulo: Brasiliense, 1981.

CRAPANZANO, V. "Diálogo". In: Anuário Antropológico, Tempo Brasileiro. Brasília: Ed. UnB, 1991. p. 59-80. 
CRAPANZANO, V. "Réflexions sur une anthropologie dês émotions". In: Terrain, 22. Paris: Patrimoines/ Ministère de la Culture et de la Communication, Fondation de la Maison des sciences de l'homme de Paris, 1994. p. 109-117.

DAJOZ, R. Ecologia Geral. Rio de Janeiro: Vozes, 1983.

DAMATTA, R. "O ofício de Etnólogo, ou como Ter "Anthropological Blues"”. In: NUNES, E. de O. (Org.). A aventura sociológica. Objetividade, paixão, improviso e método na pesquisa social. Rio de Janeiro: Zahar Eds., 1978, pp. 23-46.

DAMATTA, R. Conta de mentiroso. Sete ensaios de antropologia brasileira. Rio de Janeiro: Rocco, 1993.

DE CERTEAU, M. A invenção do cotidiano. Artes de fazer. Petrópolis: Vozes, 1994.

DEL PRIORY, M. "Biografia: quando o indivíduo encontra a história". In: Topoi, v. 10, n.19. Rio de Janeiro: UFRJ, 2009. p.7-16.

DÍAZ, R. "Personaje e identidad narrativa: una aproximación metodológica". In: Horizontes Antropológicos, n.12. Porto Alegre: PPGAS/ UFRGS, 1999. p.37-58.

DIEGUES, A.C. As áreas naturais protegidas: o mito do paraíso desabitado. Caxambu: ANPOCS, 1994.

DORST, J. Antes que a natureza morra. Por uma ecologia política. São Paulo: Edgard

Blücher Ltda, 1973.

DUBOS, R. Namorando a Terra. São Paulo: Melhoramentos/EdUSP, 1981.

DUMONT, L. O Individualismo. Uma perspectiva antropológica da ideologia moderna. Rio de Janeiro: Rocco, 1985.

DUPUY, J-P. Introdução à crítica da ecología política. Rio de Janeiro: Civilização Brasileira, 1980.

DURAND, G. As Estruturas Antropológicas do Imaginário. Lisboa: Presença, 1989.

DURAND, G. "L'anthropologie et les structures du complexe" In: Sociétés, n. 98. Bélgica/ França: De Boeck Université, 2007. p. 7-13.

ECKERT, C; ROCHA, A. L. C. O antropólogo na figura do narrador. In: O tempo e a cidade. Porto Alegre: Ed. UFRGS, 2005.

ECKERT, C; ROCHA, A. L. C. Os jogos da memória. In: Revista Ilha, n. 1. Florianópolis: UFSC, 2000. p. 71-84.

FABIAN, Johannes. "Presence and Representation: The Other and Anthropological Writing". In: Critical Inquiry, 4(16). Chicago: University of Chicago Press, 1990. p. 753-772.

FABIAN, J. "Remembering the Other: Knowledge and Recognition in the Exploration of Central Africa". Critical Inquiry, 1 (26). Chicago: University of Chicago Press, 1999. p. 49-69.

FAVRET-SAADA, J. Les mots, la mort, les sorts. Paris: Gallimard, 1977.

FAVRET-SAADA, J. "Ser afetado". In: Cadernos de Campo, n. 13. São Paulo: PPGAS/USP, 2005. p. 155-161.

GOFFMAN, I. A representação do eu na vida cotidiana, $14^{\mathrm{a}}$ ed. Petrópolis: Vozes, 2007.

GUATTARI, F. As três ecologias. Campinas, São Paulo: Papirus, 1990.

HALBWACHS, M. A memória coletiva. São Paulo: Vértice, 1990.

HOCQUENGHEM, G. A contestação homossexual. São Paulo: Brasiliense, 1980.

ILLICH, I. A convivencialidade. Lisboa: Europa-America, 1976.

INGOLD, T. The Perception of the environement. Essays livelihood, dwelling and skill. Londres: Routledge, 2000.

KLINGER, D. I. Escritas de si, escritas do outro: o retorno do autor e a virada etnográfica. Rio de Janeiro: 7 Letras, 2007.

LEZAMA LIMA, J. A expressão americana. São Paulo: Brasiliense, 1988. 
LEVI, G. Usos da biografia. In: FERREIRA, M. de M. E AMADO, J. (orgs.). Usos \& abusos da História Oral. Rio de Janeiro: Ed. da Fundação Getúlio Vargas, 1996. p. 16782.

LINDÓN, A. Récit autobiographique, reconstruction de l'expérience et fabulation: une approximation à l'action sociale. Societés, n. 87. Bélgica/ França: De Boeck Université, 2005. p. 55-63.

LUTZEMBERGER, J. Gaia, o planeta vivo. Porto Alegre: L\&PM, 1990.

MAFFESOLI, M. O imaginário é uma realidade. Revista FAMECOS, n. 15. Porto Alegre: EDIPUCRS, 2001. p. 74-82.

MARGALEF, R. Ecología. Omega: Madrid, 1982.

MATURANA, H. "Estratégias Cognitivas". In: MORIN, E. e PIATELLI-PALMARINI, M. A Unidade do Homem: invariantes biológicos e universais culturais, v.II. São Paulo: Cultrix/EdUSP, 1978. p. 148-172.

MATURANA, H. “O que se observa depende do observador". In: THOMPSON, W. I. (org.). Gaia uma teoria do conhecimento. São Paulo: Gaia, 1990.

MATURANA, H. "Conhecer o conhecer". In: Revista Ciência Hoje, v.14, n. 84. Rio de Janeiro: SBPC, 1992. p. 44-49.

McCORMICK, J. Rumo ao paraíso. A história do movimento ambientalista. Rio de Janeiro: Relume-Dumará, 1992.

NAROSKY, T. e IZURIETA, D. Guía para la identificación de las aves de Argentina y Uruguay . Buenos Aires: Asociación Ornitológica del Plata-Vázquez Mazzini Editores, 1987.

NORA, P. "Between Memory and History: les lieux de mémoire". In: Representations, n. 26. Los Angeles: University of Califórnia Press. p.7-24, 1989.

ODUM, E. P. Ecologia. Rio de Janeiro: Guanabara, 1988.

PÁDUA, J. A. (Org.) Ecologia \& política no Brasil. Rio de Janeiro: Espaço e Tempo, IUPERJ, 1987.

PEIRANO, M. G. S. Uma antropologia no plural. Três experiências contemporâneas. Brasília: EdUnB, 1992.

PEIRANO, M. A favor da etnografia. Rio de Janeiro: Relume-Dumará, 1995.

RAMBO, B. A Fisionomia do Rio Grande do Sul. São Leopoldo: Ed. UNISINOS, 1994.

REMMERT, H. Ecologia. São Paulo: EPU/EDUSP/SPRINGER, 1982.

RICOEUR, P. O si-mesmo como um outro. São Paulo: Papirus, 1991.

RICOEUR, P. Tempo e Narrativa. São Paulo: Papirus, Vol. I, 1994.

RICOEUR, P. Teoría de la interpretación. Discurso y excedente de sentido. México: Universidad Iberoamericana/Sieglo Veinteuno editores, 1995.

ROSALDO, R. "Subjetividad en el análisis social". In: Cultura y Verdad. Nueva propuesta de análisis social. México: Grijalbo, 1991. p.157-79.

SANSOT, P. Variations paysagères. Paris: Klincksieck, 1983.

SCHMIDT, B. B. "Grafia da vida: reflexões sobre a narrativa biográfica”. In: História, v. 8, n. 10. São Leopoldo: Unisinos, 2004. p. 131-142.

SCHUTZ, A. "Ação no Mundo da Vida". In: WAGNER, H. R. (org.). Fenomenologia e relações sociais. Textos escolhidos de Alfred Schutz. Rio de Janeiro: Zahar Editores, 1979. p. 123-156.

SENETT, R. O declínio do homem público. As tiranias da intimidade. São Paulo: Companhia das Letras, 1988.

SICK, H. Ornitologia Brasileira, uma Introdução, 2v. Brasília: EdUnB, 1985.

SILVEIRA,F. L. A.da. Pelas trilhas da Ilha de Santa Catarina: ecoturismo \& aventura. In: Dissertação de Mestrado em Antropologia Social. Florianópolis: UFSC, 1996. 
SILVEIRA, F.L.A.da. "Considerações sobre as relações entre cultura e natureza na Educação Ambiental”. In: GONÇALVES, T. V. O. (org.). Educação em Ciências: concepções e práticas de docência e formação. Belém: EdUFPA, 2009. p. 42-71.

SILVEIRA, F. L. A. da. "As paisagens fantásticas e o barroquismo das imagens. Estudo da memória coletiva dos contadores de causos da região missioneira do Rio Grande do Sul". In: Tese de doutorado. Porto Alegre: UFRGS, 2004. 789 pp.

SIMMEL, G. "Las Ruínas". In: Cultura Femenina y otros ensaios. Madrid: Revista de Ocidente, 1935. p. 211-220.

SIMMEL, G. Sociologia. São Paulo: Ática, 1983.

TRAJANO FILHO, W. "Que barulho é esse, o dos Pós-Modernos?". In: Anuário Antropológico 86. Rio de Janeiro/Brasília: Tempo Brasileiro/UnB, 1986. p.133-152.

TODOROV, T. "Fictions et Verités". In: L’Homme, n. 111-112. Paris: École des

Hautes Études en Sciences Sociales/ Navarin Editeur, 1989. p. 7-33.

TYLER, S. "Post-Modern Ethnography: from document of the occult to occult document". In: CLIFFORD, J. and MARCUS, G. E. (eds). Writing Culture. The poetics and politics of ethnography. California: University of California Press, 1986. p. 122-40.

WAGNER, R. A invenção da cultura. São Paulo: Cosac Naif, 2010.

WEBER, M. A ciência como vocação. Disponível em: www.lusosofia.net. Acessado em: 17 de novembro de 2010.

VELHO, O. "Os novos sentidos da interdisciplinaridade". In: Mana, 16(1). Rio de Janeiro: PPGAS/ Museu Nacional/ UFRJ, 2010. p. 213-226.

VELHO, G. Projeto e metamorfose. Antropologia das Sociedades Complexas. Rio de Janeiro: Jorge Zahar Editor, 1994.

- "Ciências sociais e biografia individual". In: Estudos Históricos, n. 38.

Rio de Janeiro: CPDOC/FGV, 2006. p. 3-9.

VIVEIROS DE CASTRO, E. "O nativo relativo". In: Mana, 8(1). Rio de Janeiro: PPGAS/ Museu Nacional/ UFRJ, 2002. p. 113-148.

Recebido em: 20/12/2010

Aprovado em: 28/03/2011 